\title{
Study of Alternative Methods for Preparing the Pitch Binder for the Anode Paste
}

\author{
Elena N. Marakushina*a, Vladimir K. Frizorger, \\ Denis G. Lazareva , Mikhail I. Krak ${ }^{\mathrm{a}}$, \\ Petr N. Kuznetsov ${ }^{\mathrm{b}}$ and Fedor A. Buryukin ${ }^{\mathrm{c}}$ \\ ${ }^{a}$ «RUSAL ETC», LLC \\ 37/1 Pogranichnikov Str., Krasnoyarsk, 660111, Russia \\ ${ }^{b}$ Institute of Chemistry and Chemical Technology of SB RAS \\ 50/24 Academgorodok, Krasnoyarsk, 660036, Russia \\ 'Siberian Federal University \\ 79 Svobodny, Krasnoyarsk, 660041, Russia
}

Aluminium smelting industry is the biggest consumer of coal tar pitch, but the use of pitch causes numerous problems because of some economic and environmental factors.

Russia's growing deficit is covered by import deliveries, which cannot guarantee a secure future. At the same time stricter environmental sanctions related to the use of coal tar pitch as a source of cancer-inducing emissions, are supporting the search for alternative raw materials and the development of new pitch binder production techniques.

Given that the known reserves of bituminous coal will be sufficient to last for 230 years at the current production rates as opposed to the oil reserves that will be enough for 40 years only, it becomes obvious that the development of a pitch binder production technique based on thermochemical processing of coals is a promising direction to follow.

Investigations were carried out to dissolve coals thermo-chemically in various organic solvents at varying levels of temperature, pressure, and reaction times. It was shown how mechanic activation and ultrasonic exposure affect the degree of organic coal mass extraction. The methods of vacuum and atmospheric distillation were used to produce pitch products from coal extracts. It was demonstrated that the use of coking additives, including nano-modified carbon, helps improve the application properties of pitch products. Large-sized samples of coal tar pitch were used to produce trial lots of anode paste for Soederberg anodes.

Keywords: Coal tar pitch, coal extraction, mechanoactivation, coal destruction, coal conversion, carbon nanomaterials, anode mass.

Citation: Marakushina E.N., Frizorger V.K., Lazarev D.G., Krak M.I., Kuznetsov P.N., and Buryukin F.A. Study of alternative methods for preparing the pitch binder for the anode paste, J. Sib. Fed. Univ. Eng. technol., 2016, 9(5), 714-723. DOI: 10.17516/1999-494X-2016-9-5-714-723.

(C) Siberian Federal University. All rights reserved

* Corresponding author E-mail address: Elena.Marakushina@rusal.com 


\section{Исследования альтернативных}

\section{способов получения связующего пека}

\section{для анодной массы}

\section{Е.Н. Маракушина ${ }^{a}$ В.К. Фризоргер ${ }^{a}$, Д.Г. Лазарева ${ }^{a}$ М.И. Крака, П.Н. Кузнецов ${ }^{\tilde{\sigma}}$, Ф.А. Бурюкин ${ }^{a} О О О$ «РУСАЛ ИТЦ»}

Россия, 660011, Красноярск, ул Пограничников, 37/1

${ }^{6}$ Институт химии и химической технологии СО РАН

Россия, 660036, Красноярск, Академгородок, 50/24

${ }^{8}$ Сибирский федеральный университет

Россия, 660041, Красноярск, пр. Свободныій, 79

Основным потребителем каменноугольного пека служит алюминиевая промыиленность, но его использование по ряду экономических и экологических причин вызывает множество проблем.

Растущий дефицит в РФ покрывается зарубежными поставками, что не имеет надежной перспективы. В то же время возрастающче экологические санкции, связанные с использованием каменноугольного пека как источника канцерогенных выбросов, заставляют искать альтернативное сырье и разрабатывать новые методы получения связующего пека.

Учитывая, что разведанных запасов каменных углей при нынешних темпах добычи хватит на 230 лет, а разведанных запасов нефти только на 40 лет, очевидно, что разработка технологии получения связующего пека термохимической переработкой углей является перспективным направлением.

Проведень исследования по термохимическому растворению углей в различных органических растворителях с варьированием температуры, давления, времени протекания реакции. Показано влияние механоактивации и ультразвукового воздействия на степень извлечения органической массы углей в экстракт. Методами вакуумной и атмосферной дистилляции получены пековые продукты из экстрактов углей. Показано, что применение коксообразующих добавок, в том числе наномодифицированного углерода, позволяет улучшить потребительские свойства пековых продуктов. Укрупненные образиь угольного пека были использованы для приготовления опьтных партий анодных масс для анодов Содерберга.

Ключевые слова: каменноугольный пек, экстракция углей, механоактивация, деструкция угля, конверсия, углеродные наноматериаль, анодная масса.

\section{Introduction}

The main consumer of coal tar pitch is the aluminium industry, but its use causes many problems for a number of economic and ecological reasons.

Currently, the main source of pitches is resin formed as a byproduct in the production of metallurgical coke by coking coal. Demands for coal tar pitch and requirements for its quality are continuously increasing in various fields, particularly in the aluminium industry. At the same time, actions taken at ferrous metallurgy companies for upgrading processes and reducing the consumption of coke lead to a decrease in production of coal tar. 
The growing shortage of coal tar pitch in the Russian Federation is covered by foreign supplies, which does not have reliable prospects. At the same time, increasing environmental penalties associated with the use of coal tar pitch as a source of cancer-causing emissions force to seek alternative raw materials and to develop new methods for the preparation of pitch binder.

\section{Petroleum coal tar pitches}

Production of alternative pitch abroad is based on the use of oil high aromatic raw materials. Pure petroleum pitch is not applicable for the production of anodes and anode paste because of the low coking ability and, as a result, poor mechanical and physical properties of the baked anode. The common practice is using a mixture of petroleum and coal tar pitch. During the industrial tests of hybrid pitches, a reduction in emissions of carcinogenic polycyclic aromatic hydrocarbons (PAHs) by $40-50$ vol. \% has been achieved, while maintaining the pot technical and economic indicators at the standard level $[1,2]$.

RUSAL ETC has developed a production technology for compound petroleum coal tar pitch that differs from the foreign technologies by that joint distillation of coal tar and petroleum tar is carried out followed by oxidation of the produced soft pitch to achieve the desired quality characteristics. Based on the technology developed, the pilot batch of compound pitch has been output and its tests in the form of anode mass have been conducted on a pot group while interchanging studs [3]. The test results indicate the pitch quality being comparable with foreign counterparts a significant decrease in PAH emissions.

However, given that the proven reserves of hard coal will last for 440 years at current rates of production in the Russian Federation, proven oil reserves will last for just 26 years [4], it is evident that the development of technology for the pitch binder using thermochemical processing of coal is a promising area.

\section{Alternative coal tar pitches}

An expedient way to solve the shortage of pitch is the creation of alternatives to production using the coke and by-product process based on the processes of pyrolysis and thermo-chemical processing of coal. Structurally, the organic mass of coal is a polymer-like solid containing oligomeric and multimeric molecules substantially of aromatic nature [5]. By acting on the structure of coal with various solvents at elevated temperatures, pressure and other factors, the intermolecular bonds between the oligomers can be destroyed, and coal extracts suitable for further processing in order to obtain pitch binder can be obtained.

This process is relatively simple technologically and can be carried out without hydrogen and catalysts. Thermal dissolution may be performed in the "soft" conditions by temperature and pressure, as there is no need for deep destruction of the organic matter of coal. The raw materials can be both bituminous and sub-bituminous coals, and brown coal.

\section{Materials and equipment}

For studies, various coals of varying degrees of coalification, of cannel (D), gas (G), gas fat (GZh), fat $(\mathrm{Zh})$ coals and lignites (2B) selected on the cuts of En + group were used. 
To conduct research on thermal dissolution, coals were pre-crushed, including grinding with mechanical activation in a laboratory hydropercussion cavitation disperser.

The solvents were anthracene oil, 1-methylnaphthalene, which have properties of both giving and attaching hydrogen.

Experiments for coal thermal dissolution were performed in a rotating autoclave having a capacity of $80 \mathrm{ml}$ and in an autoclave reactor of 2 litres in capacity fitted with a mechanical stirrer to produce products in the amount necessary to determine the technical parameters of the pitch. The process of thermal dissolution was carried out at temperatures of $350-400{ }^{\circ} \mathrm{C}$ at a pressure of $1.0-2.5 \mathrm{MPa}$ produced by solvent vapours. The heating rate was $4-5{ }^{\circ} \mathrm{C} / \mathrm{min}$, the isothermal holding duration was 1 hour to 3 hours. The ratio of carbon to solvent was 1:2.

Conversion of coal organic mass (COM) to the liquid products was determined by changing ash of raw coal and residue insoluble in quinoline.

Insoluble coal ash portion was separated from the extract by means of hot settling followed by filtration, and basic ashless extract was subjected to vacuum distillation to obtain a pitch product. To lower the amount of volatiles, the produced pitch product was oxidised in air at a temperature of $250{ }^{\circ} \mathrm{C}$.

\section{Results and discussion}

Method of mechanochemical activation along with sample grinding to high fineness stimulates the rupture of intermolecular valence bonds, alters the composition of functional groups, thereby substantially changing coal reactivity. This leads to a change in the yield of extractable substances, in the degree of conversion in the liquefaction and pyrolysis processes, in the composition of liquid and gaseous products of thermochemical conversions of coals [6].

Dispersing and hydraulic grinding occur due to exposure of a particle to the hydropercussion sequence of pulses with frequencies that are commensurable with the natural frequency of destruction of particles, that is, in the mode of resonance rupture. The frequency and amplitude of the pulses are determined by the rotor rotation frequency and the design of centrifugal hydraulic cavitation chamber of the disperser.

To study the patterns of crushing of coal in the hydropercussion cavitation disperser, a mixture of water and carbon with a fraction of over $1.0 \mathrm{~mm}$ were used. Solids content in the mixture was $67 \%$. The cavitation chamber rotor frequency was $50 \mathrm{~Hz}$. Samples were taken in the grinding process within check intervals to determine the grain-size distribution of pulverised coal.

Fig. 1 shows that the change in the amount of fraction over $0.1 \mathrm{~mm}$ as a result of coal hydraulic grinding has an asymptotic character: at the beginning of the processing, the fraction content is growing rapidly; in 15 minutes of grinding, the fraction content does not change in the further processing. It suggests the stabilising nature of the grinding process in hydropercussion cavitation disperser at a stable frequency. In our opinion, the ultimate grinding fineness will then be determined by the ratio of frequency of hydraulic impact and natural frequency of the particle destruction.

To confirm this hypothesis an experiment with a change in frequency of hydropercussion cavitation impact was conducted. Change in the disperser rotor rotation frequency from $20 \mathrm{~Hz}$ to $60 \mathrm{~Hz}$ allows adjusting hydropercussion pulse frequency in an existing structure from $0.7 \mathrm{kHz}$ to $2.0 \mathrm{kHz}$. The diagram shown in Fig. 2 illustrates the appearance of resonance milling of coal fractions 


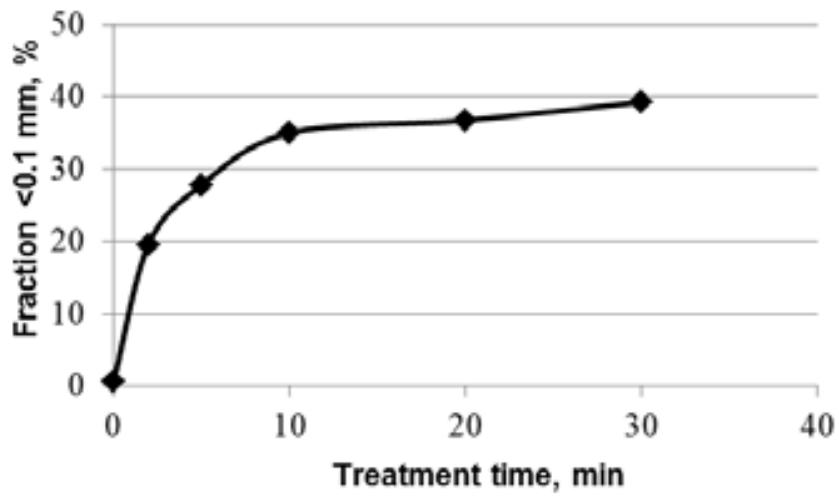

Fig. 1. Effect of coal mechanical activation time to obtain fractions over $0.1 \mathrm{~mm}$

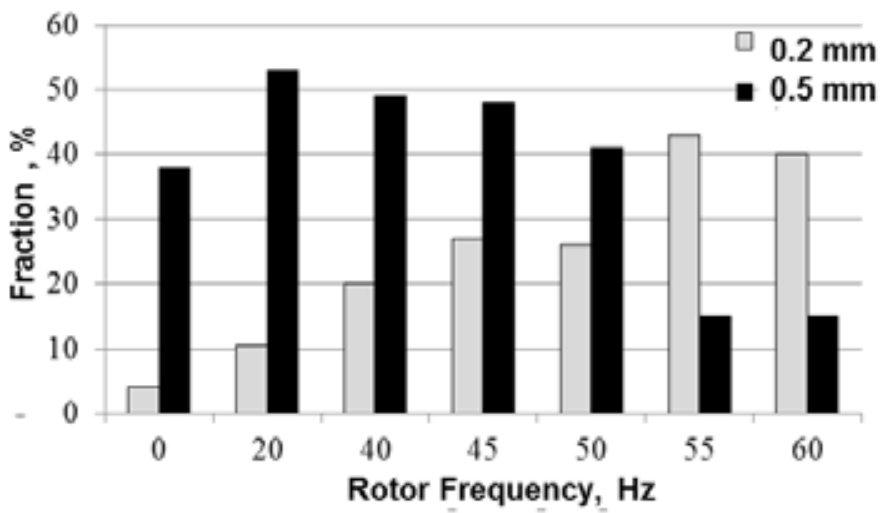

Fig. 2. Coal grinding of coal as a function of the disperser rotor frequency

over $0.5 \pm 0.2 \mathrm{~mm}$ at a rotor rotation frequency of $55 \mathrm{~Hz}$. At this frequency, a smooth decrease from $53 \%$ to $42 \%$ in the charge fraction content is replaced by a sharp jump to $15 \%$. At the same time, a parallel jump of $27 \%$ to $43 \%$. is observed in the increase in a fraction content of $0.2 \pm 0.1 \mathrm{~mm}$.

Prepared pulverised coal was subjected to thermal dissolution at elevated pressure and temperature.

Table 1 presents data on the conversion of various coals and compositions of the formed thermal dissolution products in the environment of 1-methylnaphthalene and anthracene oil as solvents and paste formers at $380^{\circ} \mathrm{C}$. When performing the process in the environment of 1-methylnaphthalene (Table 1), the greatest activity was showed by the gas fat coal (conversion of 50 wt. \% versus 32 47 wt. $\%$ for other coals). The obtained products were represented by $71.6 \mathrm{wt} . \%$ and $83.3 \mathrm{wt}$. $\%$ by toluene and quinolone soluble fractions. The content of quinoline insoluble substances was $16.7 \%$ by weight. In the environment of anthracene oil, the regular changes in the activity of coals as a function of metamorphism stage was observed: the higher stage of metamorphism of coal, the higher activity it showed during thermal dissolution. The greatest activity among the studied samples was showed by the gas fat, fat and gas coals (Table 1). For cannel coal and lignite, lower rates were obtained. For fat coal, the lowest insoluble residue of $10.8 \%$ by weight was also obtained. 
Thus, the gas fat and gas coals are preferable as a raw material from the recommended coal series based on the test results. The fat coal represents the greatest interest as a raw material for thermal dissolution.

When comparing the thermal dissolution parameters at $380{ }^{\circ} \mathrm{C}$ depending on the type of solvent used, it was found that for active gas / gas fat coals, the most favourable indicators are achieved by using anthracene oil. In case of lignite, the thermal dissolution parameters in the conditions assumed were weakly dependent on the type of solvent.

\section{Effect of temperature on the thermal dissolution parameters}

Based on the example of the most active coals, the parameters of thermal dissolution were determined as a function of reaction temperature (Fig. 3). It was found that raising the temperature from 380 to $400{ }^{\circ} \mathrm{C}$ leads to a deterioration in thermal dissolution parameters. Thus, the value of the gas fat coal conversion with an increase in the temperature of $380{ }^{\circ} \mathrm{C}$ to $400{ }^{\circ} \mathrm{C}$ decreased from $62 \mathrm{wt}$. \% to 24 wt. \%, which was probably due to thermal stimulation of competing polycondensation reactions to form carburised insoluble products.

Table 1. Parameters of coal thermal dissolution at $380{ }^{\circ} \mathrm{C}$ and reaction time of 1 hour

\begin{tabular}{|l|c|c|c|}
\hline \multirow{2}{*}{ Coal grade } & \multirow{2}{*}{$\begin{array}{c}\text { The carbon content of the } \\
\text { coal, \% Cdaf }\end{array}$} & \multicolumn{2}{c|}{ Coal conversion to liquid products, \% wt. } \\
\cline { 3 - 4 } & 73.4 & in 1- methylnaphthalene & in anthracene oil \\
\hline 2B (lignite) & 76.8 & 37 & 38 \\
\hline $\begin{array}{l}\text { DOMSSh (cannel } \\
\text { enriched coal) }\end{array}$ & 76.2 & 47 & 34 \\
\hline D (cannel coal) & 78.0 & 32 & 46 \\
\hline 2G (gas coal) & 84.6 & 50 & 62 \\
\hline 1GZh (gas fat coal) & 86.0 & - & 68 \\
\hline Zh (fat coal) & & & \\
\hline
\end{tabular}

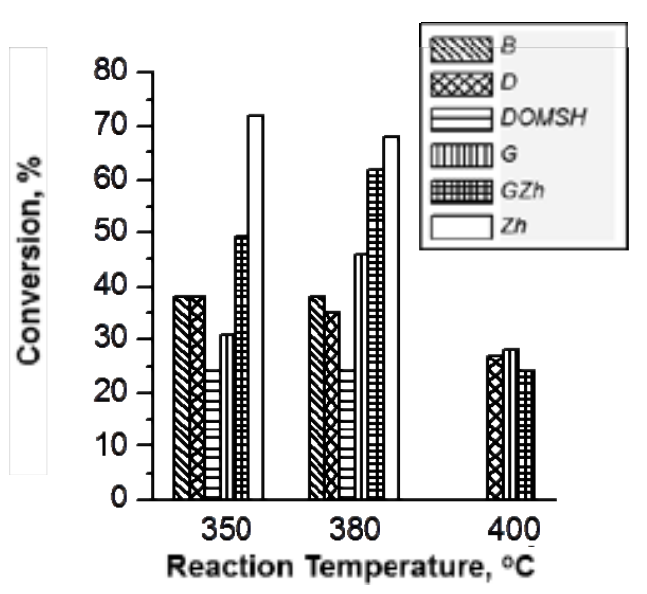

Fig. 3. Effect of temperature on the various grades coal conversion during thermal dissolution in anthracene oil (reaction time is $1 \mathrm{~h}$ ) 
In the environment of anthracene oil, thermal dissolution of gas fat and gas coals was effectively carried out at a low temperature of $350{ }^{\circ} \mathrm{C}$, the values of the conversion were $49 \%$ and $72 \%$ by weight. The products obtained were represented by $82.9 \mathrm{wt} . \%$ and $90.6 \mathrm{wt} . \%$ by the quinoline-soluble fraction, the insoluble residue content was reduced to $9-17 \%$.

\section{Effect of isothermal ageing duration on coal thermal dissolution parameters}

Experiments were performed to determine the optimal duration of isothermal holding of the reaction mixture in the autoclave for various coals at temperatures of 350 and $380{ }^{\circ} \mathrm{C}$ and for three types of coals. It was found that at a temperature of $380^{\circ} \mathrm{C}$, the isothermal holding time has a different effect on the dissolution parameters of various coals (Fig. 4). In case of low-metamorphised cannel / gas coals with the low activity, an increase in the holding time of 1 to 2 hours led to an increase in the degree of conversion by 3-24 wt. \% and in the soluble fraction content by $1-8 \mathrm{wt} . \%$. For active gas fat coal, an increase in the holding time of more than 1 hour, and in the reaction temperature is undesirable, since it worsens the thermal dissolution parameters due to the intensification of the secondary polycondensation reactions of soluble products.

At $350^{\circ} \mathrm{C}$, an increase in the isothermal holding time of 1 hour to 2 hours in all cases led to an increase in the degree of coal decomposition. The most significant increase in the conversion (from 49 to $73 \mathrm{wt}$. \%) and in the content of quinolone soluble products (from 82.9 to $90,9 \mathrm{wt}$. \%) was obtained in case of gas fat coal. The content of insoluble residue in the thermal dissolution product decreased to $9,1 \%$ wt.

Thus, as a result of the studies conducted, the following conditions to produce pitch-like products using the thermal dissolution of coal are justified:

- gas, gas fat and fat coals are preferable as a raw material;

- anthracene oil is preferable as a solvent;

- process temperature is 350 and $380^{\circ} \mathrm{C}$;

- holding period is 1 and 2 hours.

It is seen that under the assumed experimental conditions, the process is characterised in all cases by a high selectivity for the formation of sand containing product. With the thermal dissolution in anthracene oil, only a small amount of distillate fraction (less than 2 wt. \%) and a small amount of gaseous products (not more than $0.3 \mathrm{wt}$ \%) were obtained. The gas mostly contains carbon dioxide
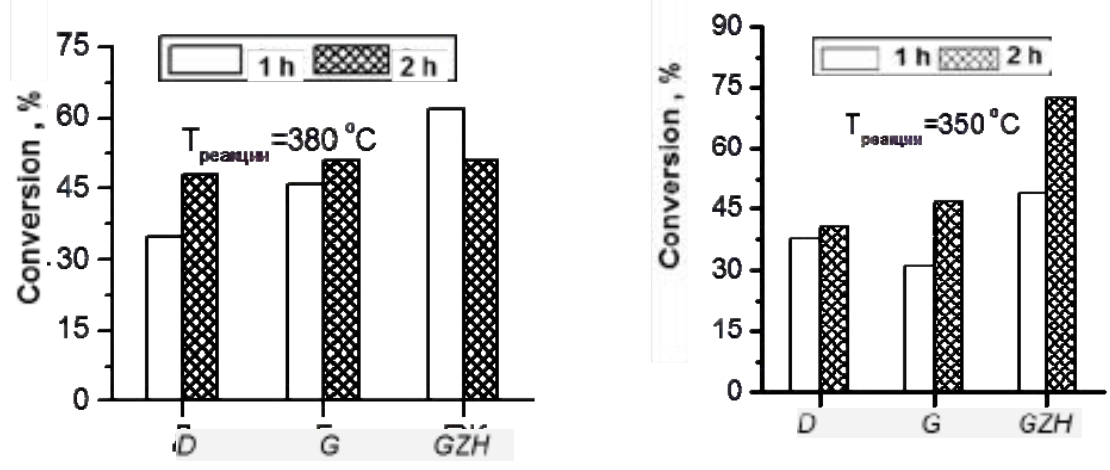

Fig. 4. Coal conversion in thermal dissolution process at a reaction time of 1 and 2 hours 
$\mathrm{CO}_{2}$, a smaller quantity of hydrogen sulphide, molecular hydrogen, $\mathrm{H}_{2} \mathrm{~S}$ and a very small quantity of carbon monoxide. Methane and other hydrocarbons were practically not formed. It follows from the data obtained that with the coal thermal dissolution in the environment of anthracene oil under the assumed conditions, predominantly selective depolymerisation reactions occur to form high-boiling and non-volatile soluble products which form the basis of pitches without a significant contribution of deep degradation reactions. The mass balance of the process is $90-94 \%$. 6-10 \% fell on the loss, which was due to pitch product sticking to the walls of the reactor, settler, and in the shutoff valves and connection fittings.

\section{Pitch product properties}

Representative samples of coal extracts were produced from gas fat, gas and fat coal grades by extraction in anthracene oil in accordance with the chosen optimal conditions. Samples of pitch products were produced by vacuum distillation of extracts with subsequent oxidation.

The yield of coal tar pitch obtained from extracts of various coal grades are in the range of $6070 \mathrm{wt} . \%$ and depend primarily on the conditions of vacuum distillation.

The obtained results of the determination of coal tar pitch quality parameters (Table 2) indicate the excess of the mass fraction of volatile substances in the test samples with respect to the desired value, the parameter value is correlated to the depth of sampling pitch product.

Additional air oxidation of pitch products allows reducing the mass fraction of volatiles by $46 \mathrm{wt}$ \%, at the same time, pitch carbon residue increases only by $2 \% \mathrm{wt}$.

It is known from the previously published data [7] that the coal tar pitch performance can be improved using additives of nanodispersed carbon. Large specific surface area of the modifier contributes to the condensation of highly volatile substances of pitch that are produced during its carbonization and to the denser structure of the produced coke. The following was used as nanomodifiers:

- fullerene $\mathrm{C}_{60}(99.5 \%)$;

- fullerene soot;

- commercial carbon, P234.

Coal tar derived from the GZhR coal grade was used as a matrix. A mixture of the coal tar pitch matrix and nanosized carbon was subjected to the ultrasonic treatment at a temperature $200{ }^{\circ} \mathrm{C}$ for 30 min. The effect of modification is determined by the "carbon residue" parameter, as summarised in Table 3.

Table 2. Quality parameters of pitch products obtained by extraction of coals in anthracene oil

\begin{tabular}{|l|c|c|c|c|c|c|c|c|}
\hline Coal grade & $\begin{array}{c}\text { Further treatment } \\
\text { of the product }\end{array}$ & $\begin{array}{c}\text { Melting } \\
\text { point, }{ }^{\circ} \mathrm{C}\end{array}$ & $\begin{array}{c}\text { Carbon } \\
\text { residue, \% }\end{array}$ & Volatile, \% & $\alpha, \%$ & $\alpha_{1}, \%$ & Ash, \% & $\begin{array}{c}\text { Benz(a)pyrene, } \\
\mathrm{mg} / \mathrm{g} \text { of pitch }\end{array}$ \\
\hline Gas fat & - & 108 & 42 & 63 & 36 & 7 & 0.2 & 4.6 \\
\hline Gas & - & 105 & 42 & 67 & 36 & 4 & 0.6 & 5.4 \\
\hline Gas & oxidation & 119 & 44 & 61 & 40 & 4 & 0.6 & 5.8 \\
\hline Fat & oxidation & 111 & 44 & 59 & 40 & 3 & 1.0 & 4.6 \\
\hline
\end{tabular}

Melting point - melting point determined using the "ring and pin" technique, ${ }^{\circ} \mathrm{C} ; \alpha$ - substances insoluble in toluene; $\alpha_{1}$ - substances insoluble in quinoline; Benz(a)pyrene - content of benz(a)pyrene. 
Table 3. Changes in the coke coal tar pitch carbon residue in modifying with various forms of nanosized carbon

\begin{tabular}{|c|c|c|c|c|}
\hline \multirow{2}{*}{ Parameter } & \multirow{2}{*}{ Unmodified pitch } & \multicolumn{3}{|c|}{ Builder, 1\% by weight } \\
\cline { 3 - 5 } & & fullerene $\mathrm{C}_{60}$ & fullerene soot & commercial carbon \\
\hline Carbon residue, \% & 42 & 48 & 47 & 45 \\
\hline
\end{tabular}

The analysis of the modification results shows that the greatest effect is achieved by using a more structured carbon, i.e. fullerene.

\section{Conclusions}

As a result of the studies performed, a laboratory technique for producing pitch binder using a method of coal thermal dissolution comprising the mechanoactivation of raw coals, obtaining carbon paste with a solvent selected, the extraction at elevated temperature and pressure, separating undissolved ash portion, and obtaining pitch product from ashless extract has been developed.

It is shown that the highest conversion into liquid products during thermal dissolution is ensured by the coals having a high stage of metamorphism, in particular, gas, gas fat and fat coals. Lignite and cannel coals are less intensively exposed to degradation under the same conditions.

The most intensely, the thermal dissolution of coal occurs at temperatures of $350-380{ }^{\circ} \mathrm{C}$ and at a pressure of 1.0 to $2.5 \mathrm{MPa}$, the conversion degree of fat coal reaches $73 \%$ wt. under these conditions.

Pitch products obtained by vacuum distillation of coal extracts are characterised by a low carbon residue.

Research continues to increase the carbon residue by oxidation of pitch products at a temperature of $200{ }^{\circ} \mathrm{C}$ and by means of modifying with nanosized carbon.

This work was performed with a support of the federal target programme titled "Research and engineering on priority areas of development of scientific-technological complex of Russia for 2014-2020" as part of the implementation of Activities 1.3 "Performing the applied research aimed at the creation of advanced scientific and technological groundwork for the development of the sectors of the economy" (Agreement No. 14.578.21.0005 dated June 5, 2015).

\section{References}

[1] Cutshall E., Mailet L. Vertical stud Soderberg emissions using a petroleum pitch blend, Light Metals, 2006, 547-551.

[2] Eidet T., Sorlie M. PAH Emissions from Soderberg with Standard and PAH-reduced Binder Pitches, Light Metals, 2004, 527-532.

[3] Фризоргер В.К., Маракушина Е.Н., Пингин В.В., Крак М.И., Лазарев Д.Г., Андрейков Е.И. Разработка и испытания компаундного нефтекаменноугольного связующего при перестановке штырей на аноде алюминиевого электролизера, Сб. докладов VI Международного конгресса «Цветные металлы и минераль- 2014», Красноярск, 2014, 810 - 815. [Frizorger V.K, Marakushina E.N., Pingin V.V., Krak M.I., Lazarev D.G., Andreykov E.I. Razrabotka i ispyitaniya kompaundnogo neftekamennougolnogo svyazuyuschego pri perestanovke shtyirey na anode alyuminievogo 
elektrolizera, Sb. dokladov VI Mezhdunarodnogo kongressa «Tsvetnyie metallyi i mineralyi - 2014», Krasnoyarsk, 2014, 810 - 815. (in Russian)]

[4] BP Statistical Review of World Energy. June 2015; bp.com/statisticalreview.

[5] Krichko A.A., Gagarin S.G. New ideas of coal organic matter chemical structure and mechanism of hydrogenation processes. Fuel, 1990, V.69, 885.

[6] Хренкова, Т. М. Механохимическая активация углей. М.: Недра, 1993. 176 c. [Hrenkova, T. M. Mehanohimicheskaya aktivatsiya ugley. M.: Nedra, 1993. 176 c. (in Russian)]

[7] Mochida I., Shimizu K., Korai Y., Sakai Y., Fujiyama S. Mesophase pitch catalytically prepared from anthracene with HF/BF3, Carbon, V. 30, 1992, 55-61. 